FACTA UNIVERSITATIS

Series: Philosophy, Sociology, Psychology and History Vol. 19, № 2, 2020, pp. 153 - 163

https://doi.org/10.22190/FUPSPH2002153A

Original Scientific Paper

\title{
MUSIC ON THE SOCIALIST BULGARIAN RADIO AS A TOOL FOR ESTABLISHING THE NATIONAL (SOCIALIST) IDENTITY
}

\author{
UDC 654.191(497.2)"1945/1989":316.75
}

\author{
Vyara Angelova \\ University of Sofia "St. Kliment Ohridski", Faculty of Journalism and Mass \\ Communication, Sofia, Bulgaria
}

\begin{abstract}
The text deals with the problems related to the Bulgarian state radio strivings during the socialism period to assist in the establishment of the national identity through the prism of the particular issue of music broadcasts. The analysis is based on archival documents consisting of minutes of the meetings of radio management, as well as relevant documents from the Bulgarian Communist Party archives. The question about the ratio of Bulgarian to foreign music on the radio not only as an element of media cultural significance but also as a national state policy arises. The presence of Western music on the radio program is studied as a result of the pressure exerted from public and state power.
\end{abstract}

Key words: Music, Bulgarian radio, socialism, national identity.

\section{INTRODUCTION}

The music radio culture of socialism in Bulgaria was studied by a number of authors (Radoslavova-Dojcheva 2010, 2013; Statelova 2019; Georgiev 2015; Dimov 2019, etc.). They take into account the establishment of a new musical style: the so-called estrada music. It should naturally help to deliver quality melodies and lyrics to the audience (aesthetic pleasure), but also to keep the audience in the field of national culture (political governance). As Dimov argues, the music is used as a "soft power" to introduce the new everyday culture into the common socialist space (Dimov 2019). The structuring of the music elements in the whole radio program should be considered an important sociological problem. The Cold War demonstrates the political and economic separation of both blocs (West and East). But when it comes to culture and music, such a disjunction was more difficult to keep. Beutelschmidt and Oehmig demonstrate with the successful expression

Received July 20, 2020 / Accepted August 8, 2020

Corresponding author: Vyara Angelova

University of Sofia "St. Kliment Ohridski", Faculty of Journalism and Mass Communication, Moscovska St 49, 1504 Sofia, Bulgaria

E-mail: v.angelova@uni-sofia.bg

(C) 2020 by University of Niš, Serbia | Creative Commons License: CC BY-NC-ND 
"connected enemies" how the opposing countries in Europe were combined through the media (Beutelschmidt \& Oehmig 2014). Deconstructing the Bulgarian socialist radio, we can explore the presence of capitalist songs as a natural element in the program, even when they were publicly stigmatized as hostile. This shows two simultaneous processes in the governance of the radio - the integration to the world radio culture and the invention of a specific socialist culture and sound.

During socialism, several parallel processes were underway: on the one hand, cultural exchange (which creates a common cultural European field) and, on the other, political control and restriction of transnational exchange of "unwanted" information (e.g. "suppression" of foreign radio stations); while the third process includes cross-border listening on both sides of the Wall ${ }^{1}$. In this sense, the picture is very complex: it is shaped by various formal and informal, legal and illegal, state and subversive activities (Badenoch, Fickers \& HenrichFranke 2013, 19)

\section{NECESSARY HISTORICAL NOTES}

Bulgarian Radio 2 was established in 1929 under the name Родно радио (Rodno Radio/Native Radio). In 1935 it was nationalized by a decree from the head of the state tzar Boris II.

On September 9, 1944, the power in Bulgaria is seized by the Fatherland Front (it includes the Bulgarian Communist Party and other parties). The Allied commission then operated in the country with representatives from the winners of World War II, under whose supervision the first necessary changes in the country were made. The Radio is among the first institutions where a change in management took place. The program was changed and adapted to the new political regime.

In 1946 a national referendum was held in Bulgaria and the country was declared a republic. Bulgaria became one of the active members of the Socialist bloc and a close ally of the Soviet Union. The geopolitical position of the state is extremely important. It is surrounded by Greece and Turkey (in some periods Yugoslavia, as well), recognized as members of the enemy bloc. By 1989 the Bulgarian Communist Party had become the single party in the country.

The radio network in the country during socialism developed in 4 nationally broadcasted programs (the first program broadcasted 24 hours a day starting from 1974) and 5 regional programs. The radio remained a state monopoly until the end of the Socialist Bloc.

On November 10, 1989, the communist leader Todor Zhivkov (in power from 1954) was overthrown and the dismantling of the socialist system in the country began.

In 1992 private radio stations started broadcasting in the country. The Radio and Television Act from 1998 declared the current status of the Bulgarian National Radio as a public media.

\footnotetext{
${ }^{1}$ Authors of interesting works on the subject of cross-border listening of radio stations and watching of neighboring television stations in the Balkans include Annemarie Sorescu-Marinkovic (Sorescu Marinkovic 2018) and Svetlana Antova (Antova 2018).

${ }^{2}$ Bulgarian radio was nationally and internationally known also under the name Radio Sofia. In this text, the author uses both names to refer the Bulgarian state radio during socialism.
} 


\section{RADIO AND THE NATIONAL IDENTITY}

"National identity" is a social construct, a collection of different (individual and collective) attitudes towards the nation. ${ }^{3}$ As much as the socialist state was characterized by the full penetration of party-state discourse in every sphere of public and private life, we can assume that "national identity" is managed as an imaginary community (according to Anderson 1983) fully ideologically centralized. Under these circumstances, the radio played a major role in the early years, being the only electronic media at the beginning of the socialist period. Later, television joined this function. As Eric Louw claimed, "the media (especially television) have become the main storytelling vehicle, journalists have become the key (but not only) players in the myth-making and identity building" (Louw 2005 , 97). This includes the invention of new national heroes - guerrillas, politicians, socialist authors, etc. and the abandonment of the old ones - labeled as bourgeois, formalists, etc. National identity during socialism cannot be considered outside the notions of a "socialist nation". The concept of a specific "socialist nation" appeared to be a brand new concept for society and the people. While preserving the characteristics of a classic understanding of a nation (e.g. ethnos, language, territory, cultural heritage, etc.) the idea (based on the philosophy and political views of Marx and Lenin) gives it a new interpretation. The concept - a construct of Soviet politicians (also perceived as acting philosophers) also includes the Socialist International, which should help to bring about the gradual integration of fraternal socialist countries. In the processes of the building of these new sociopsychological formations, all the resources of government are harnessed: from education and work to leisure and culture.

In this text, we are particularly interested in the problem of how music as an essential element of the radio program is included in the national identity-building processes. The analysis is based on archival documents from minutes and protocols of meetings of the radio management, as well as relevant documents from the Bulgarian Communist Party archives. Interviews with 26 employees of the Bulgarian socialist radio, conducted in 2018 , were partly analyzed as a reference framework.

One of the important questions refers to the national origin of broadcasted music. In the post-socialist period, the strongly mythologized speech prevailed, according to which only Bulgarian music was broadcasted on Bulgarian radio, and foreign music was subjected to strict scrutiny and censorship. While in the speech elements it is easier to trace the monolithic nature of the ideological discourse, in the case of music, things seem much more complicated. Universal music language knows no borders and languages and finds its followers regardless of restrictions or borders. The phenomenon "Lili Marlene" - a song which could be heard from both sides of the front during World War II, is just one piece of evidence that music can unite friends and enemies. And that is why political restrictions on the musical repertoire (of radio stations) around the world are monitored all over the world (recall the attitude of Hitler and Stalin towards jazz; the moralistic prohibitions of the song by Serge Ginsburg and Jane Birkin in the USA, etc.). A hidebound usage of music as a tool for the building of national identity during socialism joins the common radio ether, dividing and uniting the world by different melodies.

\footnotetext{
${ }^{3}$ Barrett notes 7 components which are included in the concept of national identity, where the core are the subjective feelings and perception of belonging to the nation, the internalization of stereotypes about "us" and "others", as well as the willingness to follow the national culture and norms (Tartakovsky 2010, 1851).
} 


\section{BULGARIAN VS FOREIGN MUSIC: THE BATTLE}

The symbolic battle took place on the ground of the realization of a national radio program (a concept that appeared intensely in the documents from the 1960s) and the understanding that Bulgarian radio is a part of the national identity and security (by the way, this concept is widely shared on both sides of the Iron Curtain). In the first place, the use of music coming from socialist countries naturally occupied the biggest part of the program. Not only because they shared a common political bloc, but also because the exchange between socialist countries was easier. But, not always and not the whole musical fund from the so-called "fraternal countries" was broadcasted. The reasons were various. Politically, not all of the socialist countries were seen as stable partners in different periods of socialism, such as Yugoslavia and Albania. But also, the technical and content quality (music, text, and performance) of the music records were not always considered to have a good enough quality to be broadcasted. Western music, on the other hand, is recognized as a part of the adversary bloc, but it is also more expensive - copyright regulations are more restrictive and enforced. At the same time, both the Radio and the State understand that it is impossible to broadcast a program without Western music. And here we are not talking about taking care of the listening culture. The reason is the consideration of the possibility (and the practices) of people to turn to foreign radio stations - the preferences are for the more diverse-sounding radio Belgrade, radio Bucharest (in certain periods), radio Skopje, radio Ankara, along with Western "Free Europe" or the Voice of America.

After 1954, Bulgarian radio organized regular meetings with the public in the capital and the country (in large and small cities, and in villages) for discussions of the program. The discussions and the most important posts are well monitored and discussed by the radio authorities. Due to their diversity, these meetings have little direct relevance for the decisions about the radio program. However, some repeated requests were later used as an argument for some programming changes. Meetings rather had the goal to create a more stable connection with the people and to represent the public character of the radio, like in other countries. These meetings joined not only common listeners (the public) but also correspondents of radio in the country (professionals), as well as representatives of local party assets (ideological workers). Such a mixed composition explains why a great number of messages are a clear demonstration of "desirable social behavior". But besides that, people really are excited by the radio and have the most diverse demands.

One of the topics where listeners are particularly active is the music. It outlines both the deficits in the radio program and the aesthetic attitudes of the listeners. The idea of a national program, as a symbol of national identity, is evident here. What did the listeners want (based on documents for the period 1954-1962)? Their desires were often contradictory. For example - they wanted more folk music, but there are too many folk songs; they demanded more operas and symphonic music because we need more of our famous opera performers, but someone confessed that we are weak in opera music and sometimes the listener is bored with classical music. There were voices that the radio broadcast many Macedonian songs ("We have become a Yugoslav republic") 4 and open requests for more Bulgarian music - songs for the entire Bulgarian nation. The public demanded more dancing and fun music ("Why do our people like to listen to more music on Radio Bucharest? Very simply, because it is more tenable"). ${ }^{5}$

\footnotetext{
${ }^{4}$ CSA, f. 206 , i. 2 A.U. 17 , p. 48

${ }^{5}$ CSA, f. 206, i. 2 A.U. 17 , p. 7
} 
In 1954 the management of the Radio organized meetings in two large Bulgarian cities - Blagoevgrad and Simitli. There were about 1,000 people in Blagoevgrad and 500 in Simitli. The report of the event is very worrying and detailed. For the first time, representatives of the radio were not welcome and they were not accepted warmly and benevolently by the audience. The emphasis of the report is that the "heavy shadow of radio Skopje" prevailed during the conversation. It was followed with greater interest, and even some small radio stations in the villages broadcasted the program from Skopje and not from Sofia. The main reason for this practice was again the music. On the one hand, we have the difficult question about what our music is on the Balkan. Everybody in the public has their own clear and undoubted definition of what Bulgarian music means in comparison to other Balkan states. And of course, everyone insists on having their own view, shared on the radio. But when we talk about folklore songs drawing definitive national lines, that is a very difficult task. Mainly because it is always a question of state policy to encourage people to think in desirable national forms and formats. The case in Blagoevgrad and Simitli shows how difficult it was to create a national identity using music in a region (Macedonian) whose musical heritage combined the music of several countries. On the other hand, besides the origin, there is also the aesthetic motivation to choose a foreign radio station. Someone in the public declared: "Some folk songs were put on the radio just because a song had to be released" and the dissatisfaction of the music was described by the listeners' feelings, such as: "Sometimes you get the impression of some dizziness." 6

So, the pressure from the public dictates the whole sound of Radio Sofia in the same way that the interests of the state power do. The musical choice on the socialist Bulgarian radio had to follow certain criteria. Thus, despite the strict restrictions, in practice more Western melodies penetrated socialist Bulgaria than Eastern melodies found their way out onto the Western European air. This proves that the Iron Curtain was "more permeable" from West to East than vice versa (Angelova 2018b; Badonoch, Fickers \& Henrich-Franke 2013).

Table 1 Ratio of Bulgarian-foreign music content

\begin{tabular}{|c|c|c|c|c|c|c|c|}
\hline No matter the genre & 1950 & 1954 & 1958 & 1961 & 1963 & 1964 & 1968 \\
\hline Bulgarian & $30 \%$ & $23 \%$ & $27,86 \%$ & $60-65 \%$ & $65-75 \%$ & $13 \%$ & $32 \%$ \\
\hline Soviet & $70 \%$ & $30 \%$ & $19,40 \%$ & & & $11 \%$ & $24 \%$ \\
\hline People's Democratic countries7 & & $10 \%$ & $25,87 \%$ & & & $32 \%$ & $10 \%$ \\
\hline West & & $35 \%$ & & $40-45 \%$ & $30-35 \%$ & $36 \%$ & $40 \%$ \\
\hline Yugoslav & & & $0,33 \%$ & & & & \\
\hline Macedonian & & & $0,35 \%$ & & & & \\
\hline
\end{tabular}

NOTE: The data were obtained from official documents of the Institutional Archive of Bulgarian radio. The number, categorizations of countries, and given percentages have varied over the years. In 1968 the percentage sum increased to 106, which could be explained by the illustrative character that the radio management gave to the numbers. These data cannot fully take into account the fact that some of the musical works have foreign authorship, but are performed by Bulgarian musicians (especially symphonic music). Some of the foreign pop songs were translated and performed by Bulgarian artists.

\footnotetext{
${ }^{6}$ CSA, f. 206, i. 2, A.U. 17, pp. 39-44

${ }^{7}$ The term People's Democratic countries is frequently used in official documents. It refers to the countries from the Socialist Bloc - the German democratic Republic, Czechoslovakia, Romania, Hungary, and Poland.
} 
Initially, the program of the Bulgarian Radio was strongly connected with the Soviet Radio. The main music fund came from there. As can be seen from the 1950 data, the radio program (see Table 1) was highly dependent on Soviet works. Gradually the fund was significantly enriched with Bulgarian music and the ratio of Bulgarian to foreign production changed.

First of all, in the mid-1950s and early 1960s, there was a lot of talk about the need to build a national image of the program. In 1954, the Collegium of the Ministry of Education and Culture found that music programs "do not have a bright national image and that there is no thematic focus in music programs". ${ }^{8}$ This provoked discussions whether Western music really predominates (the radio workers were partly ready to admit that it was actually significantly present in the program) or it was just a feeling. In order to realize the project for a national program, Radio Sofia needed a large volume of musical works, and "The recordings of Bulgarian works are too few and cannot give it [the program] a national look". ${ }^{9}$ It is not clear precisely how they imagined the national character of the program. Possibly, it was chimerically imagined as entirely Bulgarian, but rather it was meant that the predominant part of the program was to be self-made, and not as it was found to be in 1960 . "Bulgarian pop and dance music in quantity and character is lost among the foreign music and cannot convey the national image of the program at all". ${ }^{10}$ The illusion that a specific Bulgarian radio sound could be established was actively maintained almost until the end of the socialist period. The topic of the capitalist-socialist music ratio remained on the agenda.

"The most significant weakness of the light music program is that there is no national image; that not a small part of it consists of Western music. Our main task and our desire are to promote the national pop and dance music, the music of the Soviet peoples, of the socialist countries, and only the best examples of the music of the capitalist countries" ${ }^{11}$ Among Western music, "Italian and French songs predominate, and partially the music of the Latin American countries. English and American music have been represented to ae much lesser extent". ${ }^{12}$

After the measures taken to increase the production of Bulgarian pop songs, the problem seemed to have been solved. But it was not. Because the hours of the radio program over the years increased. And any increase in airtime required more and more music to avoid repetitions. Can one then rely on the music of the socialist countries to fill this void? Hardly, because "from the socialist countries the music is not brightly original and in some cases it is made worse than the western models", and "besides, most of the records we receive from Hungary, the GDR, Czechoslovakia, Poland and Romania (and some from the Soviet Union) are too extreme and go beyond the criteria for a piece of good music which Radio Sofia has adopted, and therefore are not approved, which further narrows down the available amount of recordings used for program preparation". ${ }^{13}$ In general, "the pop music received through the official exchange from the socialist countries is not sufficient in quantitative terms. There was a significant reduction in the influx of Soviet music in particular [in 1973]. In some cases, the music from other fraternal countries was not at the required ideological and artistic level - it lacked national identity, originality, and high

\footnotetext{
${ }^{8}$ CSA, f. 206 , i. 6 , A.U. 2 , p. 28

${ }^{9}$ CSA, f. 206, i. 6, A.U. 2, p. 31

${ }^{10}$ CSA, f. 206 , i. 5 , A.U. 3 , p. 141

${ }^{11}$ CSA, f. 206, i. 5, A.U. 3, p. 140

${ }^{12}$ CSA, f. 206, i. 5, A.U. 3, p. 141

${ }^{13}$ CSA, f. 206 , i. 13 , A.U. 8 , pp. 8
} 
mastery, it carried an element of imitation. ${ }^{14}$ What was worse was that, although smaller in terms of amount, Western music impressed listeners and "selected Western music with its bright melodies, masterful orchestrations, virtuoso performance, and high-quality recordings was etched in the listener's mind and left lasting impressions". ${ }^{15}$

Nevertheless, Radio Sofia put effort into maintaining the balance in the program between Bulgarian-Western and socialist music. Arbitrariness occurred only in rare cases: "in their desire to increase the popularity of the shows, to make them more demanded amongst the working people, some editors began to play much sharper-sounding Western pop and dance music, causing serious distortion of the ratio between Bulgarian and foreign music, resulting in the change and disappearing of the program's national image of pop and dance music". ${ }^{16}$

An attempt was made to reduce the amount of played popular music as a mechanism to reduce the amount of Western music. It lasted several months. "In the last 6-7 months, the volume of the pop and dance music in the radio program has decreased, which allowed the reduction of Western vocal music and the increase of Bulgarian and Soviet music. The lower percentage of music from the socialist countries was the result of some reduction in the volume of the pop and dance music from Czechoslovakia, Yugoslavia, and Romania, which occurred recently“. ${ }^{17}$

As a consequence, this approach led to the dissatisfaction of the listeners which was used by the Bulgarian radio executives to legitimize the role of Western music on the air, whose amount, in fact, never completely disappeared. "Radio Sofia must also broadcast Western pop and dance music, but selecting only the best, ideologically, and artistically sound pieces. The names of the great performers from the western countries became popular and the listeners started looking for them. If Radio Sofia did not broadcast the best performances, the listeners and especially the young people would look for them on Western radio stations". ${ }^{18}$ It was clear that the best music from the West should be offered to the listeners (as understood by the relevant commissions), because "if they do not find it on Radio Sofia, [the listeners] with just one turn of the dial of the radio, would listen to it in great abundance from any foreign radio station, which made it too easy and convenient a way for vulgarity, inaction, and perversion to penetrate the airwaves". ${ }^{19}$

The criteria for "suitable" Western music for broadcasting changed over the years. In the 1970s it was already recognized that "we pay a lot of attention to the so-called "engaged" songs that appeared in the West in the last two decades. Performances by world-renowned singers - Pitt Seeger, Bob Dylan, Joan Baez, Leo Ferre, Jacques Brel, Jean Ferrat, Johnny Cash, Gianni Morandi, George Harrison and many more were broadcasted. However, we have to admit that the recordings of all the bright and great representatives of the world pop art are not delivered quickly and on time. In this way, our young people are forced to look for them on foreign radio stations". ${ }^{20}$

This raises the question - how is the Bulgarian Radio supplied with Western music? The answer is simple - legally and illegally. Legally - by purchases of foreign records and recordings received from the foreign radio stations, and illegally through "transcripts from microplates and very little from the ether. Private individuals were searched for anything

\footnotetext{
${ }^{14}$ CSA, f. 206 , i. 11 , A.U. 2 , pp. 70

${ }^{15}$ CSA, f. 206, i. 5, A.U. 3, pp. 143

${ }^{16}$ CSA, f. 206, i. 13, A.U. 6, pp. 134

${ }^{17}$ CSA, f. 206, i. 13 , A.U. 6, pp. 69

${ }^{18}$ CSA, f. 206, i. 13 , A.U. 8, p.8

${ }^{19}$ CSA, f. 206, i. 13 , A.U. 7, pp. 7

${ }^{20}$ CSA, f. 206, i. 11 A.U. 2, pp. 173
} 
that could be useful for our program. However, this approach was too uncertain and could not always provide us with a regular record supply ... Rerecorded Western music with lyrics was listened to a second time with an interpreter to prevent play on the microphone even in a piece of foreign language music with a bad and awkward text". ${ }^{21}$ This practice of supplying the radio with Western music by private individuals continued during late socialism, as testified by music editors (Angelova 2020, 242-244). Rosemary Statelova defined the supply of music by private individuals as a comprehensive but also quite unmanageable inflow. "It has the advantage of being the fastest, most up-to-date, and also the most diverse in terms of content" (Statelova 2011, 30). According to her, there are two main sources for replenishing the Radio's Music Library: "studio sound production of executive ensembles and mechanical production - re-recordings of recordings received through various channels" (Statelova, 2011, p. 29)

Not all Bulgarian music wins recognition (just because it is). In 1975, the measures taken against poor quality products were reported. "Pursuant to the decisions of the February Plenum, a major review of the fund of pop songs was made. Most of the songs with weak lyrics were removed from the program".22

The drive for a national radio program led to an abundance of mediocre musical performances. In 1977 it was acknowledged that: "In the production of pop music an extremely important issue is the discrepancy between a large number of songs and plays needed for the programs of Radio Sofia and the relatively limited creative potential and capacity of Bulgarian authors in this genre. The great shortage of Bulgarian artistic pop songs and instrumental pieces has often led to lowering the criterion for their acceptance and, ultimately, to compromises of an artistic and aesthetic nature. In this way, songs without special merits have crept in - only because the Radio's programs need more "national pop". ${ }^{23}$ (Stoyan Mihailov, head of the Department of Propaganda and Agitation of the Central Committee of the Bulgarian Communist Party in 1983). ${ }^{24}$

The solution for all this was the previously denied import from abroad: "Against the invasion of pop music, sometimes with dubious artistic quality, often composed by our non-professional authors, with compromises in terms of performance, we oppose very carefully selected music received through the exchange with foreign or most often rerecorded gramophone records of various forms with high quality in terms of professional creativity and performing arts". ${ }^{25}$

The pendulum has swayed to the other end. From the struggle to obtain a national sound to the denunciation of "national sounding" as a cover for mediocre songwriters and composers.

The point of view of the journalists who worked in the socialist Bulgarian radio often differed from the analyzed data from the documents. Some shared the existence of quotas for Bulgarian and foreign music, ${ }^{26}$ especially restrictive for Western artists (between $5 \%$

\footnotetext{
${ }^{21}$ CSA, f. 206 , i. 5 A.U. 3 , pp. 145

${ }^{22}$ SA-Sofia, f. 4040 B, i. 2 A.U. 3, pp. 32

${ }^{23}$ SA-Sofia, f. 2920 B, i. 7 A.U. 1 , pp. 17

${ }^{24}$ SA-Sofia, f. 2920 B, i. 7 A.U. 1, pp. 48

${ }^{25}$ SA-Sofia, f. 2920B, i. 7 A.U. 1, pp. 17

${ }^{26}$ Ivelina Vatova shares an important view of how foreign music was categorized, "There was a great scale of what music to play. It was obligatory that 60 or $70 \%$ of the music be Bulgarian, $30 \%$ foreign. As foreign music was divided into Soviet, Eastern bloc and Western - that meant whatever remained. Usually, in an hour and a half or two, you played one or two pieces of Western music. Italian music was very popular then. It was something, though" (Angelova 2020, 239).
} 
to $20 \%$ from the whole program). However, they also remembered that in the last decade of socialism, the 1980s, the amount of Western music increased significantly. Music editor Enyu Chakarov shared that the listeners' interest in national hits, however, remained. Journalist Petar Punchev testified about the internal battle between the programs on Radio Sofia over who should take the "cool music", targeting Western music (Angelova 2020, 238-240).

The socialist man found himself both closed in his socialist world and at the same time consuming the capitalist culture chosen by the media. In this sense, we can conclude that the national socialist identity, "produced" by the Bulgarian Radio is a specific combination of the officially proclaimed ideological vision and the cultural practices nonpublicly supported by the government.

\section{CONCLUSION}

The studied examples of the changing perceptions of the foreign - Western-capitalist as an antipode of the Bulgarian-socialist illustrate the changes in the political perceptions of the rulers.

The process of formation of the socialist nation is key to understanding the functioning of Bulgarian radio in the period 1944-1989. It explains some of the policies that took place through and in radio - composing the radio program and institutionbuilding on the example of the Soviet Union (as a leading socialist state) until the mid1950s; but also, the actions of building a national radio program with a strong Bulgarian sound (after the 1960s). The development of the activities was not consistent, they were often forceful (Radio Sofia obeyed the instructions of the party and the state), and often mutually exclusive. But the participation of Bulgarian radio in the formation of the nation should not be seen as a specific feature of the socialist media alone. In this sense, Bulgarian Radio is no exception. It is part of the common European processes marked by opposition during the Cold War, mainly, in the patronizing behavior of the state media towards the audience. It is perceived as subject to education and modeling in the spirit of political doctrine in each country. In the general case, this is done through a broad cultural cultivation of the people, which includes music. Political indoctrination takes place much more efficiently and more deeply through the messages of a culture understood in the broadest sense. However, the idea of an isolated socialist nation remains controversial as a realization. Public socialist discourse acquires semantic satiation, where repeated words and clichés lose their meaning. By implementing Western music in a controlled manner in the program of the Bulgarian Radio and stimulating national music production, the government is trying to keep its audience. Thus, at the end of socialism, it turned out that the Eastern European public (including the Bulgarian one) knew the Western cultural industry far better than expected. 


\section{REFERENCES}

Angelova, Vyara. Bulgarskoto radio prez sozialisma/ Bulgarian radio during socialism (1944-1989) (Doctor of science diss.). Sofia: University of Sofia "St. Kliment Ohridski", 2020.

Angelova, Vyara. "Forming the 'Socialist nation' through television (1960-1980) in Bulgaria. TV programs for children”. Rhetoric and Communication 34 (2018a). Accessed 10 June 2020. Available at: http://rhetoric.bg/ viara-angelova-forming-the-socialist-nation-through-television-1960-1980-in-bulgaria-tv-programs-for-children

Angelova, Vyara. "Bulgarskoto radio prez sozialisma. Profesionalnite medijni izdania/ Bulgarian Radio During Socialism. Professional Media Outlets (1944-1989)". Medialog 4 (2018b). Accessed 10 June 2020. Available at: http://www.medialog-bg.com/?p=1523

Anderson, Benedict. Imagined Communities: Reflections on the Origins and Spread of Nationalism. London: Verso Editions and New Left Books, 1983.

Antova, Svetlana. "Prisustvie na jugoslavskite medii vuv vsekidnevnia zivot na horata ot belogradchishkata granochna zona pres 70-te I 80-te godini na $20 \mathrm{vek} /$ Presence of the Yugoslav media in the daily life of the people from the Belogradchik border area in the 70s and 80s of the 20th century". In Through the Past to the Future. Collection in Honor of Prof. DNA Margarita Karamihova, edited by Petko Petkov. Prosveta, 2018.

Badenoch, Alexander, Andreas Fickers and Christian Henrich-Franke. Airy Curtains in the European Ether: Broadcasting and the Cold War. Nomos, 2013.

Beutelschmidt, Thomas and Richard Oehmig. "Connected Enemies? Programming Transfer Between East and West during The Cold War and The Example of East German Television". VIEW - Journal of European Television History and Culture 3, 5 (2014).

Georgiev, Momchil. Za balgarskoto nazionalno radio i bulgarskata muzikalna kultura / About Bulgarian National Radio and Bulgarian music culture. Sofia: Grajdanski institute, 2015.

Dimov, Ventsislav. Muzika za naroda na medijnia front (Mekata vlast na narodnata i populyarnata muzika) / Music for the People on the Media Front (The Soft Power of Peoples and Popular Music in Socialist Bulgaria). "St. Kliment Ohridski" University Press, 2019.

Louw, Eric. The Media and Political Process. London: SAGE, 2005.

Radoslavova-Dojcheva, Antoaneta. Iz istoriyata na Radio Sofia/ From the History of Radio Sofia. V. Turnovo: DAR-RH, 2013.

Radoslavova-Dojcheva, Antoaneta. Muzikata v bulgarskoto radio / The Music in Bulgarian Radio (1930-1944). Sofia: Petko and Pencho Slaveykovi, 2010

Sorescu-Marinkovic, Annemarie. $S$ druge strane granice, Jugoslovenska televizija $i$ druge uspomene iz svakodnevnog zivota Rumuna u Banatu / On the Other Side of the Border. Yugoslav TV and Memories of Everyday Life of Romanians in Banat. Timișoara: Uniunea Sârbilor din România, 2018.

Statelova, Rosemarie. Estrada i sozializam - problyasazi / Estrada and Socialism - Reflections. Sofia: Riva, 2019.

Statelova, Rosemarie. Prez godinite. Rosemarie Statelova na 70 godini / Through the years. Rosemarie Statelova of 70 years. IAS-BAS, 2011

Tartakovsky, Eugene. "National identity". In Encyclopedia of Adolescence, edited by Roger J. R. Levesque, 1850-1962. New York: Springer, 2011.

Documents from Central State Archive, Republic Bulgaria (CSA) and State Archive - Sofia (SA-Sofia), cited in the text:

CSA, f. 206, i 2-13 - Administration of Radio information and Television

Contains: PMS, orders, decisions, etc. on creation, organization, registration and re-registration (1945-1990); structures (1970-1985); minutes with annexes from meetings of the EB (1950-1985), the Program Council (1968-1970), the TEC (1973-1985); activity programs (1980); concepts for development up to 2000 (1981); reports and information from the management to higher organizations on the activity (1972-1980); work protocols, reports, information, etc. on international activity (1960-1985); the COMECON agreements (1981-1985); regulations by the President on the use of the Golden Fund (1980-1985); instructions and regulations (1974-1980); five-year plans and plans for the overall activity (1978-1980; 1990); annual plans and reports, reports, inquiries, information, etc. by qualification of the staff (1978-1985); reports, information and analyzes on the social development of the team (1981-1985); national occupational safety program (1981-1985); annual labor protection plans (1976-1984); annual reports and budgets (1979-1984); annual balance sheets with explanatory notes (1949, 1980-1985); staffing schedules (1961-1984).

SA- Sofia, f. 4040B, i. 2 - Institutional Party Committee (CPC) at the Committee for Television and Radio - Sofia.

Contains: Minutes of: the reporting and election conference of the CPC (1975), the meetings of the CPC (19741975), etc.

SA-Sofia, f.2920, i.7 - Institutional Party Committee (CPC) at the Committee for Television and Radio - Sofia

Contains: Minutes of meetings of the CPC and the materials to them (1978-1979); Minutes of the reporting and election conference and the materials to it (1978). 


\section{MUZIKA SOCIJALISTIČKOG RADIJA BUGARSKE KAO NAČIN USPOSTAVLJANJA NACIONALNOG (SOCIJALISTIČKOG) IDENTITETA}

Tekst se bavi problemima koji se odnose na burgarski nacionalni radio u pokušajima da uspostavi nacionalni identitet kroz emitovanje muzičkih programa. Analiza se bazira na arhivskom materijalu koji čine tačke sastanaka uprave radija, kao i sva relevantna dokumenta iz arhive Bugarske komunističke partije. Odnos učestalosti bugarske muzike prema učestalosti inostrane muzike na radiju nema samo kulturni značaj, već se na osnovu njega formira nacionalna politika. Prisustvo zapadnjačke muzike na radio programu analizira se kao posledica pritiska publike na državnu vlast.

Ključne reči: muzika, nacionalni radio Bugarske, socijalizam, nacionalni identitet. 